\title{
Bilateral lotus petal flap reconstruction for perianal Paget's disease
}

\author{
Ugo Grossi ${ }^{1,2}$. Giulio Aniello Santoro ${ }^{1} \cdot$ Elisa Antoniazzi ${ }^{3} \cdot$ Francesco Dell'Antonia $^{3} \cdot$ Enrico Busato $^{4}$. \\ Giorgio Berna ${ }^{3}$. Giacomo Zanus ${ }^{1}$
}

Received: 11 May 2020 / Accepted: 23 June 2020 / Published online: 30 June 2020

(c) The Author(s) 2020

A 65-year-old female patient with a history of intermittent pruritus for the past 2 years, presented with erythematous plaques with white scaling in the perineal, vulvar and perianal regions. Skin biopsy was consistent with Paget's disease [1]. Given the extension of the lesions, a wide local excision and bilateral lotus petal flap reconstruction was carried out by an institutional multidisciplinary panel (Figs. 1, 2) [2, 3]. The patient recovered uneventfully. The surgical wounds healed completely without flap compromise and there was normal sphincter function at the 3-month follow-up (Fig. 3).

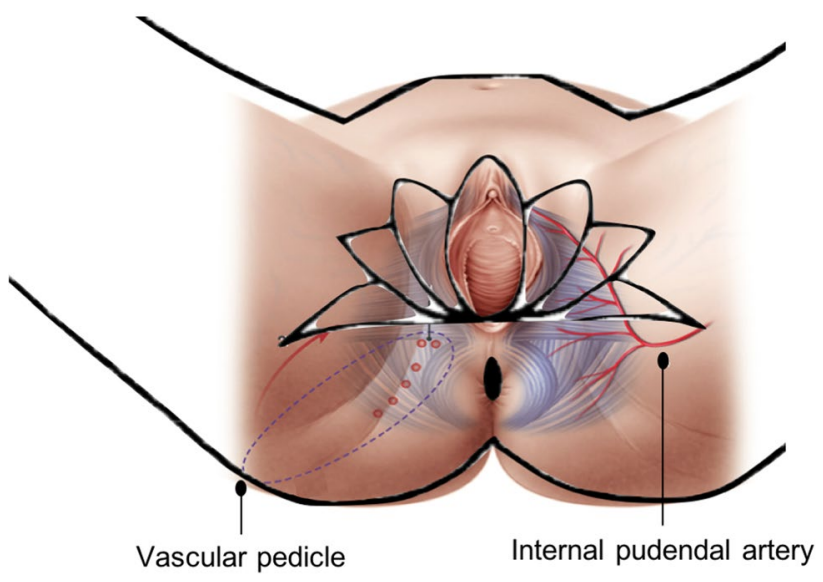

Fig. 1 Schematic representation of the lotus petal flap reconstruction

Ugo Grossi

ugo.grossi@aulss2.veneto.it

1 Tertiary Referral Pelvic Floor and Incontinence Centre, DISCOG, Treviso Regional Hospital, University of Padua, Treviso, Italy

2 National Bowel Research Centre, Queen Mary University of London, London, UK

3 Department of Plastic and Reconstructive Surgery, Treviso Regional Hospital, Treviso, Italy

4 Department of Obstetrics and Gynecology, Treviso Regional Hospital, Treviso, Italy 

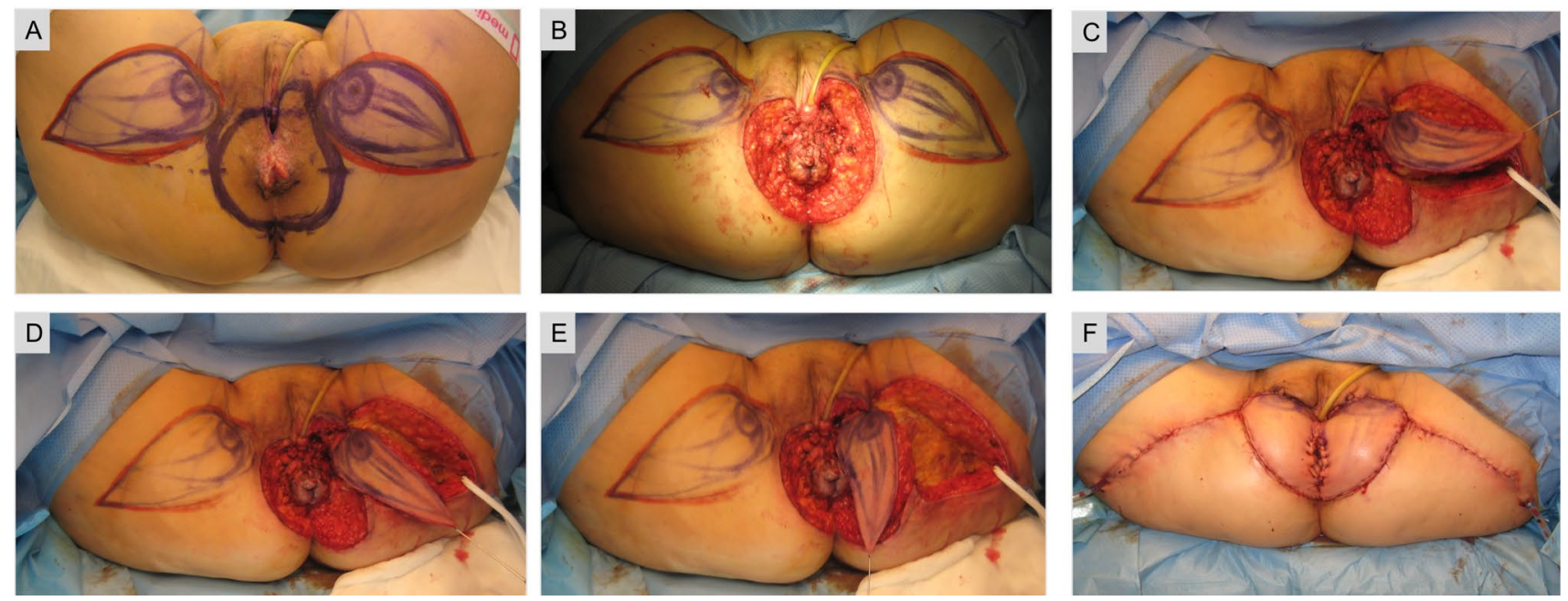

Fig. 2 Flap planning was performed with handheld Doppler ultrasound to detect perforators of the internal pudendal artery. The excision included all visible lesions in the perianal skin and the posterior part of the vulva, with a $2 \mathrm{~cm}$ margin of healthy tissue (a). The outer $1.5 \mathrm{~cm}$ of the urethra were mobilized and the transverse perineal muscles exposed, along with the external anal sphincter (b). Two fascio- cutaneous lotus petal flaps were centred over the medial thigh crease bilaterally. They were elevated in an posterior-to-anterior direction and posteriorly rotated with a $90^{\circ}$ angle to cover the perianal defect. A Foley urinary catheter was left in situ for a total of 7 days $(\mathbf{c}-\mathbf{e})$. Immediate postoperative result after flap in-setting and primary closure of the donor site (f)
Fig. 3 The patient was continent to faeces and urine, with no signs of wound infection, breakdown or haematoma at 4 (a) and 12 weeks (b) postoperatively


Funding None reported.

\section{Compliance with ethical standards}

Conflict of interest The authors declare that they have no conflict of interest.

Ethics approval All procedures performed in studies involving human participants were in accordance with the ethical standards of the institutional and/or national research committee and with the 1964 Helsinki declaration and its later amendments or comparable ethical standards.

Informed consent Informed consent was obtained from the participant included in the study.

Open Access This article is licensed under a Creative Commons Attribution 4.0 International License, which permits use, sharing, adaptation, distribution and reproduction in any medium or format, as long as you give appropriate credit to the original author(s) and the source, provide a link to the Creative Commons licence, and indicate if changes were made. The images or other third party material in this article are included in the article's Creative Commons licence, unless indicated otherwise in a credit line to the material. If material is not included in the article's Creative Commons licence and your intended use is not permitted by statutory regulation or exceeds the permitted use, you will need to obtain permission directly from the copyright holder. To view a copy of this licence, visit http://creativecommons.org/licenses/by/4.0/.

\section{References}

1. Gaertner WB, Hagerman GF, Goldberg SM, Finne CO (2008) Perianal Paget's disease treated with wide excision and gluteal skin flap reconstruction: report of a case and review of the literature. Dis Colon Rectum 51(12):1842-1845

2. Yii NW, Niranjan NS (1996) Lotus petal flaps in vulvo-vaginal reconstruction. Br J Plast Surg 49(8):547-554

3. Hollenbeck ST, Toranto JD, Taylor BJ, Ho TQ, Zenn MR, Erdmann D, Levin LS (2011) Perineal and lower extremity reconstruction. Plast Reconstr Surg 128(5):551e-563e

Publisher's Note Springer Nature remains neutral with regard to jurisdictional claims in published maps and institutional affiliations. 